\title{
循環不全を背景とするめまいの治療成績
}

$\begin{array}{lccr}\text { 斎藤 } & \text { 富康・森㟢 } & \text { 京子・戸村 } & \text { 義則 } \\ \text { 藤原 } & \text { 宏寿・浅井 } & \text { 栄司・菱田 } & \text { 登 } \\ \text { 時田 } & \text { 喬 } & & \end{array}$

\section{Therapeutic Results in Patients with Vertigo due to Circulatory Insufficiency}

\author{
Tomiyasu Saito, Kyoko Morisaki, Yoshinori Tomura, \\ Hirotoshi Fujiwara, Eiji Asai, Noboru Hishida \\ and Takashi Tokita
}

(Gifu University)

Fifty-two patients with chronic vertigo associated with underlying circulatory insufficiency were treated with 3-6 mg of Dihydroergotamine daily for about 4 weeks and followed for changes in (1) subjective vertigo, (2) vestibular function, (3) signs of disorders of the inner ear and central nervous system, (4) predisposing conditions, and (5) associated symptoms. Each sign, symptom or abnormal test result was graded as mild, moderate or severe. The therapeutic results were rated on a 5-point scale: marked, moderate, or slight improvement, no change or aggravation in comparison to the pretreatment level.

(1) The improvement rate for subjective vertigo was $69 \%$.

(2) For vestibular function, the improvement rate was $25 \%$ for voluntary nystagmus, $48 \%$ for the Romberg test, $56 \%$ for the writing test, a test of deviation reaction, and $52 \%$ for the stepping test.

(3) Those with disorders of the inner ear and central nervous system showed no improvement by audiometry, but in the test for nystagmus caused by labyrinthine stimulation, the improvement rate was $38 \%$.

(4) In regard to predisposing conditions, the improvement rate for OD symptoms was $73 \%$ and that for Schellong's test was $55 \%$.

(5) Relief of associated symptoms was high for nausea and vomiting (70\%) and headache $(50 \%)$.

\section{はじめに}

内耳・脳の循環不全が原因と思われるめまい例は多い。しかし，循環不全においても血栓・出血 で一定の血管の支配領域の障害が明瞭なむのは診断も容易であり, 内科的に治療されることが多 い.耳鼻咽喉科のめまい外来で対象となる症例は，乙のような症状は明確でなく，めまいのみが訴 
えであり他の症状がそしい例が多い。 また循環不全とめまいの関係む明確に捉え難い例が多い. こ れに対し, 岐阜大学耳鼻咽喉科では素因調査, 負荷平衡機能検査を行い, めまいと循環不全の関係 を把握し, 診断している.

このような症例の治療においては，(1)患者の訴えるめまいに対する効果をみるのみでなく，(2)め まいの他覚的所見である平衡機能に対する効果, (3)内耳・中枢神経症状がある時はその機能に対す る効果，(4)めまいの素因を把握しえた時はその素因に対する治療効果を検討する必要がある.

本論文では循環不全を背景とするめまいの治療効果を，このような判定法で検討した結果を報告 するものである.

\section{治 療 対 象}

昭和57年 1 月より昭和57年12月までに岐㚖大 学耳鼻咽喉科を受診しためまい・平衡障害患者 は 521 名であった。このうち素因検査を実施し たのは 372 名であった。素因検査の結果，循環 不全を背景としたのは372名中227名であった. その内訳は表 1 の如くであった.
このうち，薬物療法を実施し，経過観察しえ た症例は52例である。乙の内訳は内耳循環不全 12 例, 脳循環不全 5 例, 内耳 - 脳循環不全 2 例, 起立性調節障害（OD）30例, 低血圧 3 例 であった。この52例は全て慢性のめまいを訴え た症例である.

表 I 循環不全を背景とした症例（227例）と治療経過観察対象（52例）（）は例数

\begin{tabular}{|c|c|c|c|c|}
\hline 障害部位 & 断 & 背 & 治療経過観 & 察対象 \\
\hline \multirow{3}{*}{$\begin{array}{c}\text { 迷 路 } \\
(57)\end{array}$} & 内耳循環不全 （40） & 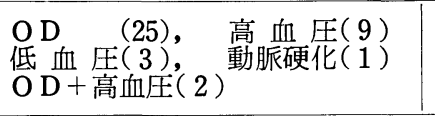 & \multirow[t]{3}{*}{ OD } & \multirow[t]{2}{*}{ (12) } \\
\hline & $x=エ ー ル$ 病 $\quad(10)$ & 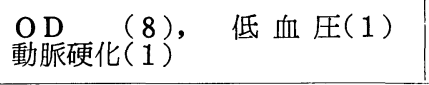 & & \\
\hline & 前庭型 $x=エ ー ル$ 病 $(7)$ & OD $\quad(7)$ & & \\
\hline 中 $(30)^{\text {枢 }}$ & 脳循環不全 （30） & $\begin{array}{l}\mathrm{OD} \\
\mathrm{O} \text { 低 }\end{array}$ & OD & ( 5 ) \\
\hline $\begin{array}{c}\text { 迷路十 } \\
\text { 中枢 } \\
(6)\end{array}$ & 内耳・脳循環不全（6） & O D （5), 動脈硬化(1) & O D & (2) \\
\hline \multirow[t]{2}{*}{$\begin{array}{r}\text { 全 身 } \\
(134)\end{array}$} & 循環系異常 （133） & 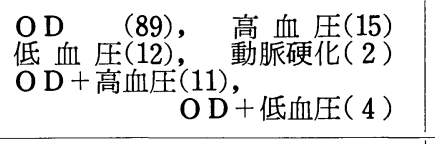 & $\begin{array}{l}\text { OD } \\
\text { 低血圧 }\end{array}$ & $\begin{array}{l}(30) \\
(3)\end{array}$ \\
\hline & 自律神経系異常 （1） & アシュネル, ツェルマック陽性 (1) & & \\
\hline
\end{tabular}

\section{治 療 方 法}

Dihydroergotamine（DHE）を 1 日 3 回食 後経口投与した．原則として投与量は体重 $50 \mathrm{~kg}$ 以上のとき $6 \mathrm{mg}, 50 \mathrm{~kg}$ 以下のとき $3 \mathrm{mg}$ とした. 投与期間については 4 週間としたが，来科しな
くなったり, 無効のため短くなったり, 効果が あったが不充分なため長くなったりした。 ま た，単独投与を原則とした. 


\section{治療効果の判定}

(1) 検討事項

検討事項及びその検查方法は次の如くであ

る.

1. めまいに対する効果

自覚するめまい

2. 平衡機能に対する効果

自発眼振運動検査

直立検査

偏倚検查
3. 内耳・ 中枢神経障害に対する効果 惪力検查

迷路刺激検企

視運動性眼振検査.

4. 素因に対する効果

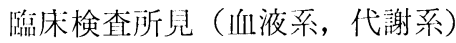

O D症状

Schellong 起立試験

負荷平衡機能検査

表 2 症状・所見の程度分類

\begin{tabular}{|c|c|c|c|c|c|}
\hline 項 & 目 & 程 度 & 軽 & 中 等 度 & 高 \\
\hline \multicolumn{3}{|c|}{ 自覚するめまい（慢性） } & 仕事ができる & 仕事ができない & 就休を要する \\
\hline \multirow{3}{*}{$\begin{array}{l}\text { 平 } \\
\text { 衡 } \\
\text { 機 }\end{array}$} & \multicolumn{2}{|r|}{ 自発眼振（頻度） } & 10 打/11秒以上 & 10 打 / 6 秒 10秒 & 10 打/ 5 秒以下 \\
\hline & \multirow{2}{*}{ 直 } & 開 & $\begin{array}{l}\text { 単脚起立姿勢維持 } \\
\text { 時間30秒以下 }\end{array}$ & $\begin{array}{l}\text { マン姿勢維持時間 } \\
\text { 30秒以下 }\end{array}$ & $\begin{array}{l}\text { 両脚起立にて動摇 } \\
\text { もしくは転倒 }\end{array}$ \\
\hline & & 閉 & $\begin{array}{l}\text { 単脚起立姿勢維持 } \\
\text { 時間10秒以下 }\end{array}$ & $\begin{array}{l}\text { マン姿勢維持時間 } \\
\text { 30秒以下 }\end{array}$ & $\begin{array}{l}\text { 両脚起立にて動摇 } \\
\text { もしくは転倒 }\end{array}$ \\
\hline \multirow[t]{2}{*}{ 能 } & \multirow{2}{*}{ 偏 } & 書 & 偏書角度 $6^{\circ} \sim 9^{\circ}$ & 偏書角度 $10^{\circ} \sim 18^{\circ}$ & 偏書角度 $19^{\circ}$ 以上 \\
\hline & & 足 & 回転角度 $45^{\circ} \sim 90^{\circ}$ & 回転角度 $91^{\circ} \sim 180^{\circ}$ & 回転角度 $181^{\circ}$ 以上 \\
\hline \multirow{4}{*}{$\begin{array}{l}\text { 内 } \\
\text { 耳中 } \\
\text { - 枢 } \\
\text { 神 } \\
\text { 経 } \\
\text { 障 } \\
\text { 害 }\end{array}$} & \multicolumn{2}{|c|}{ 聴力検査(主要会話周波数聴力レベルの癸均) } & $25 \sim 40 \mathrm{~dB}$ & $41 \sim 60 \mathrm{~dB}$ & $61 \mathrm{~dB}$ 以上 \\
\hline & \multirow{2}{*}{$\begin{array}{ll}\text { 迷 } & \text { 検 } \\
\text { 路 } & \\
\text { 刺 } & \\
\text { 激 } & \text { 查 } \\
\end{array}$} & C P. D P & $20 \sim 40 \%$ & $41 \sim 60 \%$ & $61 \%$ 以上 \\
\hline & & 回転後眼振持続時間 & $41 \sim 45$ 秒 & $46 \sim 50$ 秒 & 51梨以上 \\
\hline & \multicolumn{2}{|c|}{ 視運動性眼振検査（眼振数の低減） } & $20 \sim 40 \%$ & $41 \sim 60 \%$ & $61 \%$ 以上 \\
\hline \multirow{8}{*}{ 素 } & \multirow{2}{*}{$\begin{array}{l}\text { 臨 } \\
\text { 床 } \\
\text { 检 } \\
\text { 查 } \\
\end{array}$} & 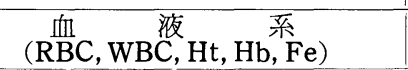 & $\begin{array}{c}\text { 異常項目数 } \\
1\end{array}$ & 異常項目数 & $\begin{array}{l}\text { 異常項目数 } \\
3 \sim 5\end{array}$ \\
\hline & & $\begin{array}{l}\text { 代 蛋白, 榭 質, 糖) } \\
\text { 采 }\end{array}$ & 異常項目数 & 異常項目数 & 異常項目数 \\
\hline & \multicolumn{2}{|r|}{$\mathrm{D}$ 症状 } & $\left\{\begin{array}{l}\text { 大 } 1 \\
\text { 小 } 3\end{array}\left\{\begin{array}{l}\text { 大 } 2 \\
\text { 小 } 1\end{array}\{\right.\right.$ 大 3$\}$ & $\left\{\begin{array}{l}\text { 大 } 2 \\
\text { 小 } 3\end{array}\left\{\begin{array}{l}\text { 大 } 3 \\
\text { 小 }\end{array}\{\right.\right.$ 大 4 & $\left\{\begin{array}{l}\text { 大 } 3 \\
\text { 小 } 3\end{array}\left\{\begin{array}{l}\text { 大 } 4 \\
1\end{array}\{\right.\right.$ 大 5 \\
\hline & \multicolumn{2}{|c|}{ Schellong 起 立 試 験 } & + & $H$ & $H$ \\
\hline & \multirow{4}{*}{$\begin{array}{l}\text { 低 } \\
\text { 血 } \\
\text { 压 } \\
\text { 最 } \\
\text { 大 } \\
\text { 血 } \\
\text { 压 }\end{array}$} & 20 歳未満 & $100 \sim 96 \mathrm{mmHg}$ & $95 \sim 91 \mathrm{mmHg}$ & 90mmHg以下 \\
\hline & & 20～40歳未満 & $110 \sim 106 \mathrm{mmHg}$ & $105 \sim 101 \mathrm{~mm} \mathrm{Hg}$ & 100mmHg以下 \\
\hline & & 40～60歳未満 & $115 \sim 111 \mathrm{mmHg}$ & $110 \sim 106 \mathrm{mmHg}$ & 105mmHg以下 \\
\hline & & 60歳以上 & $120 \sim 116 \mathrm{mmHg}$ & $115 \sim 111 \mathrm{mmHg}$ & 110mmHg以下 \\
\hline \multirow[t]{2}{*}{ 因 } & \multirow[t]{2}{*}{ 負 } & 重心動摇（cm） & $\begin{array}{l}\text { 前後 } \\
2.8 \sim 3.9 \\
\text { 左右 } \\
2.0 \sim 2.4\end{array}$ & $\begin{array}{l}\text { 前後 } \\
4.0 \sim 8.0 \\
\text { 左右 } \\
2.5 \sim 5.0\end{array}$ & $\begin{array}{c}\text { 前後 } \\
8.1 \sim \text { or 転倒 } \\
\text { 左右 } \\
5.1 \sim \text { or 転倒 }\end{array}$ \\
\hline & & 脈拍減少（1 分間） & $10 \sim 19$ & $20 \sim 29$ & $\begin{array}{l}\text { 心停止, 眩量, 虚脱 } \\
\text { などがある場合 }\end{array}$ \\
\hline & 随 & 症 & あるが気になら & $\begin{array}{l}\text { 気になるが, 仕事の } \\
\text { 支障にならない }\end{array}$ & 仕事の支障になる \\
\hline
\end{tabular}


5. 随伴症状に対する効果

以上の検討事項のうち，自覚するめまい，O D症状，随伴症状については患者に『めまい症 状日誌』を毎日記録させた。 その他の検査につ いては，投楽前，投楽 2 週間後， 4 週間後， 8 週間後に検査を施行した。患者の都合でこの全 ての時期に検査しえていない例むある.

(2) 症状・浙見の程度分類

各々の検討項目の症状・所見を軽度異常, 中 等度異常, 高度異常の 3 段階に程度分類した

（表2）。なお，OD症状についてはOD研究 班によるO D診断基準を採用した。

(3) 治療効果の判定法

症状・所見の程度分類に対応して点数を与 え，治療前と投与終了後の点数を比較して治療 効果を判定した，すなわち，異常なし 0 点，軽 度異常 1 点, 中等度異常 2 点, 高度異常 3 点之
し，その点数に基づき表 3 の如く, 著明改善, 中等度改善, 軽度改善, 不変, 悪化の 5 段階に 評価した。

表 3 評価基準

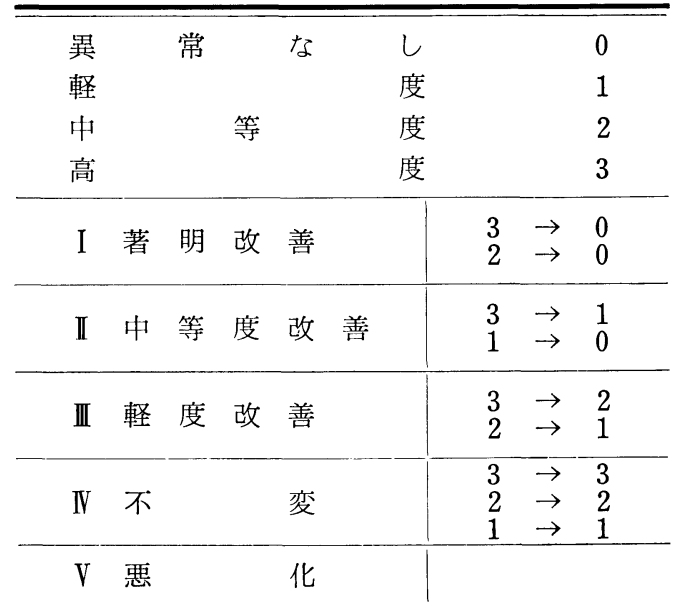

\section{治 療 成 績}

\section{（1）めまいに対する効果（表 4）}

自覚するめまいに対する効果は52例中, 著明 改善 9 例, 中等度改善 23 例, 軽度改善 4 例, 不 変16例であった．改善率は69\%である.

(2) 平衡機能に対する効果（表 5 ）

自発眼振は治療前陽性は50例中 4 例であった が，4例中治療により軽度改善 1 例, 不变 3 例 であった．改善率 $25 \%$ である。

直立検查は治療前異常は35例中27例であった が, 治療により著明改善 4 例, 中等度改善 3 例, 軽度改善 6 例, 不变 14 例であった. 改善率 は $48 \%$ である。

偏倚検査のうち, 書字検査は治療前異常が27

表 4 めまいに対する効果

\begin{tabular}{|c|c|c|c|c|c|c|c|}
\hline & 改善度 & $\begin{array}{l}\text { 著 } \\
\text { 明 } \\
\text { 改 } \\
\text { 善 }\end{array}$ & $\begin{array}{l}\text { 中 } \\
\text { 等 } \\
\text { 度 } \\
\text { 改 } \\
\text { 善 }\end{array}$ & $\begin{array}{l}\text { 軽 } \\
\text { 度 } \\
\text { 改 } \\
\text { 善 }\end{array}$ & 不 & 悪 & $\begin{array}{l}\text { 改 } \\
\text { 善 } \\
\text { 度 }\end{array}$ \\
\hline $\begin{array}{l}\text { 自覚する } \\
\text { めまい }\end{array}$ & 52 & 9 & 23 & 4 & 16 & & $\begin{array}{l}36 / 52 \\
(69 \%)\end{array}$ \\
\hline
\end{tabular}

例中16例で，治療により著明改善 1 例，中等度 改善 7 例, 軽度改善 1 例, 不変 7 例であった, 改善率 $56 \%$ である. 足踏検査では治療前異常が 28 例中 21 例で，治療により著明改善 1 例，中等 度改善 10 例, 不変 5 例, 悪化 5 例であった. 改 善率 $52 \%$ である。

（3）内耳・中枢神経障害に対する効果（表 6) 恥力検査は治療前異常は 48 例中 6 例で, 治療 成績は 6 例全て不変であった。

迷路刺激眼振検査は治療前異常は36例中 8 例 で，治療により著明改善 1 例，中等度改善 1 例，軽度改善 1 例，不変 5 例であった. 改善率 $38 \%$ ある。

視運動性眼振検査は治療前 4 例に施行し 3 例 に異常を認めるも，全例とも経過は追えなかっ た。

（4）素因に対する効果（表 7）

臨床検查血液系では, 治療前異常は 12 例中 3 例で, 治療により中等度改善 1 例, 不変 2 例で あった，代謝系では，治療前異常は12例中 8 例 で, 治療により中等度改善 2 例, 不変 6 例であ 
った。

O D症状に対する効果は表 8 亿示した，治療 前異常が52例中45例であった，治療により著明 改善13例, 中等度改善15例, 軽度改善 5 例, 不 変12例であった．改善率は73\%である．大症状 ・小症状共に有効な症例が多く, 大症状では市。 ちくらみ $64 \%$ ，入浴時気持ちが悪くなる63\%， 小症状では乗物酔い79\%に有効であった。

Schellong 起立試験では, 治療前異常は44例 中30例で, 治療により著明改善 3 例, 中等度改 善12例, 軽度改善 2 例, 不変 11 例, 悪化 2 例で
あった，改善率は55\%である。

低血压は 3 例認め, 著明改善 1 例, 不変 2 例 であった。

負荷平衡機能検査のうち, 起立検査は治療前 異常は施行した22例全例で, 治療により軽度改 善 6 例, 不変 13 例, 悪化 3 例であった. 改善率 は27\%である.

(5) 随伴症状に対する効果（表 9)

随伴症状のうち, 特に効果の認められたのは 悪心・呕吐, 頭痛であった。悪心・呕吐症例は 23 例で, 治療により著明改善 5 例, 中等度改善

表 5 平衡機能に対する効果

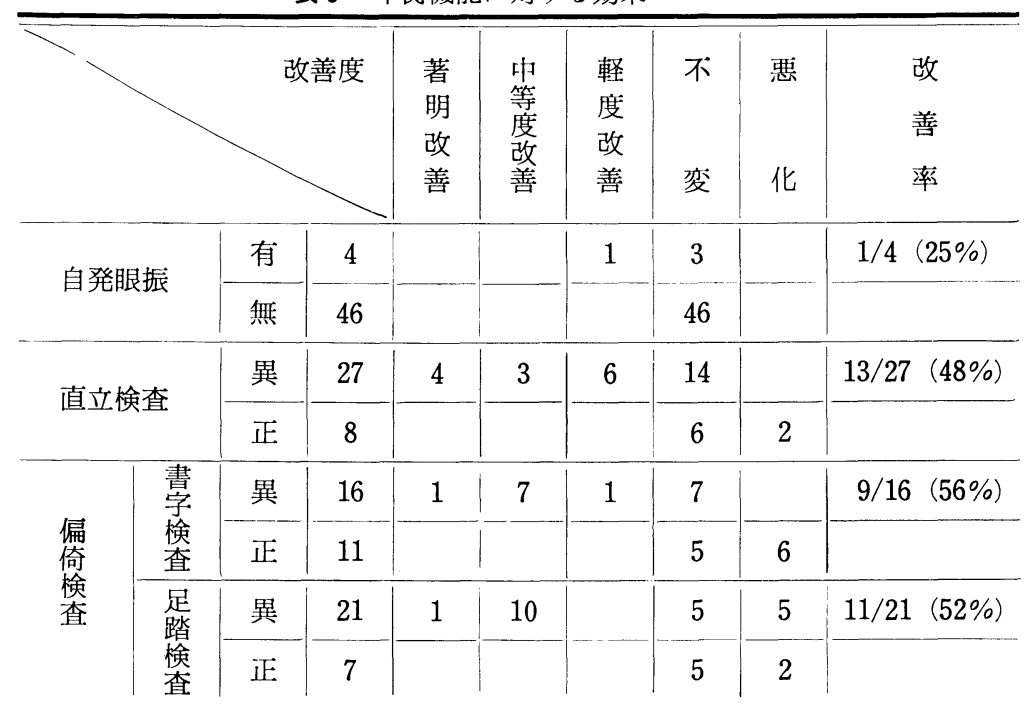

表 6 内耳・中枢神経障害に対する効果

\begin{tabular}{|c|c|c|c|c|c|c|c|c|}
\hline & \multicolumn{2}{|c|}{ 改善度 } & $\begin{array}{l}\text { 著 } \\
\text { 明 } \\
\text { 改 } \\
\text { 善 }\end{array}$ & $\begin{array}{l}\text { 中 } \\
\text { 等 } \\
\text { 度 } \\
\text { 改 } \\
\text { 善 }\end{array}$ & $\begin{array}{l}\text { 軽 } \\
\text { 度 } \\
\text { 改 } \\
\text { 善 }\end{array}$ & $\begin{array}{l}\text { 不 } \\
\text { 変 }\end{array}$ & 悪 & $\begin{array}{l}\text { 改 } \\
\text { 善 } \\
\text { 率 }\end{array}$ \\
\hline \multirow{2}{*}{ 聴 力 検 査 } & 異 & 6 & & & & 6 & & $0 / 6(0 \%)$ \\
\hline & 正 & 42 & & & & 42 & & \\
\hline \multirow{2}{*}{ 迷路刺激検查 } & 異 & 8 & 1 & 1 & 1 & 5 & & $3 / 8 \quad(38 \%)$ \\
\hline & 正 & 28 & & & & 27 & 1 & \\
\hline \multirow{2}{*}{ 視運動性眼振検查 } & 異 & 3 & & & & & & \\
\hline & 正 & 1 & & & & & & \\
\hline
\end{tabular}


10例，軽度改善 1 例，不変 7 例であった．改善 率は70\%である。頭痛症例は40例で，治療によ り著明改善 7 例, 中等度改善 9 例, 軽度改善 4 例，不変20例であった. 改善率は50\%である.
逆に効果の少なかったのは耳鳴で，30例のう ち治療により著明改善 5 例, 中等度改善 3 例, 不変22例であった．改善率は27\%である.

表 7 素因に対する効果

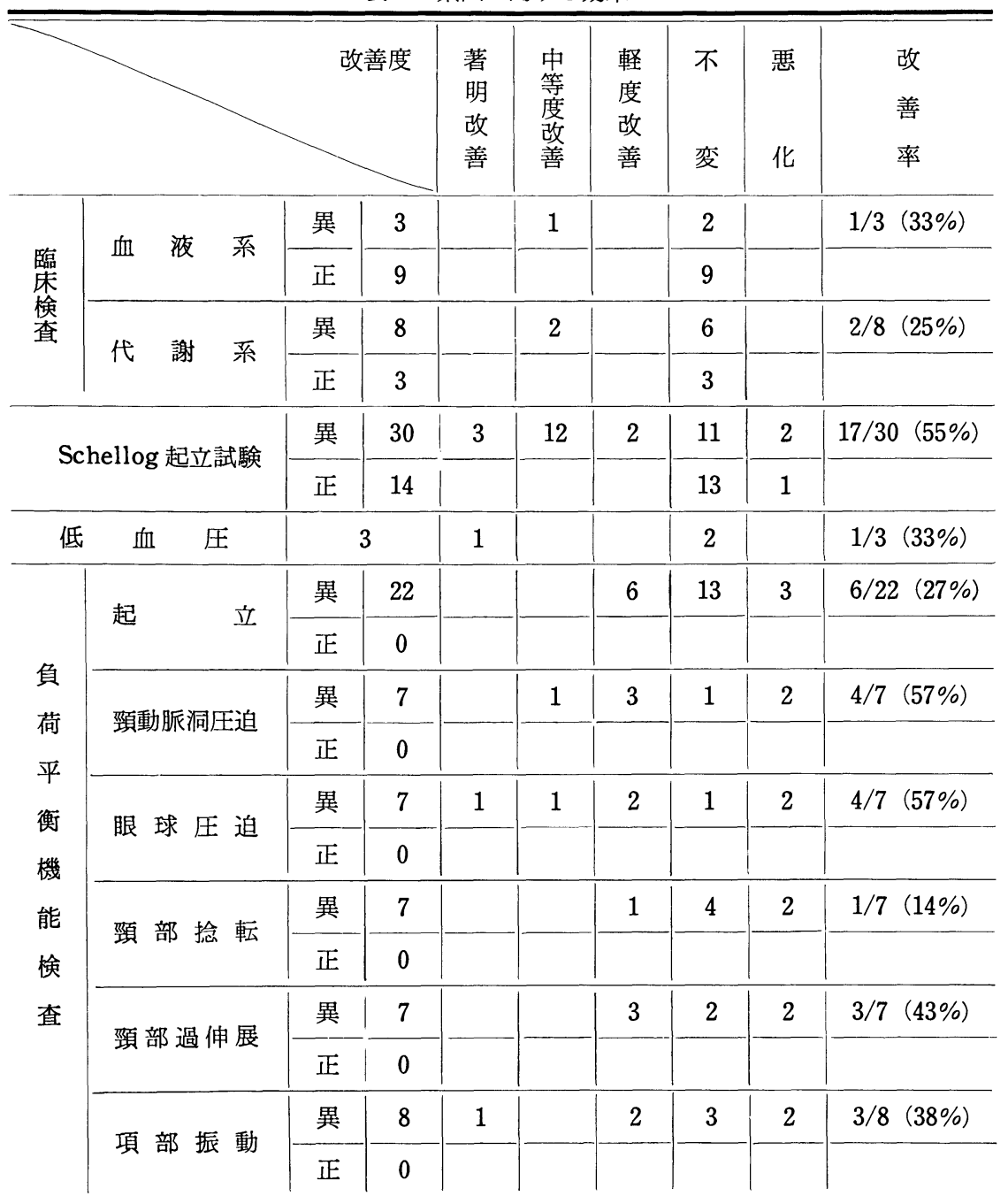

考

1) 治療効果判定法について

一般的にめまい症例に対する治療効果の判定

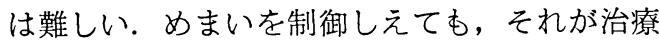
効果によるものか, 自然経過による症状の消退 かは判定しかねることあ多くある。また，めま
按

い発作は消失してむ，内耳障害や不定愁訴が残 ることあある。

時田ら $(1980)^{1)}$ はメニエール病の治療にあた っては，(1)めまい（発作期・間歇期）に対する 治療，(2)内耳障害に対する治療，(3)めまい発作 
の反復に対する治療が必要であり，治療効果の 評価もとれに対応して行う必要があると述へてて いる.

そして，めまい発作の反復に対する治療効果 の判定の基準としては AAOO (American
Academy of Ophthalmology Otology) では 治療前の平均発作間隔の10倍以上の期間定期的 発作 (definitive spell) がない時, めまいが 制御されたと判定されている.

発作性のめまいについては以上のような観点

表 80 D症状に対する効果

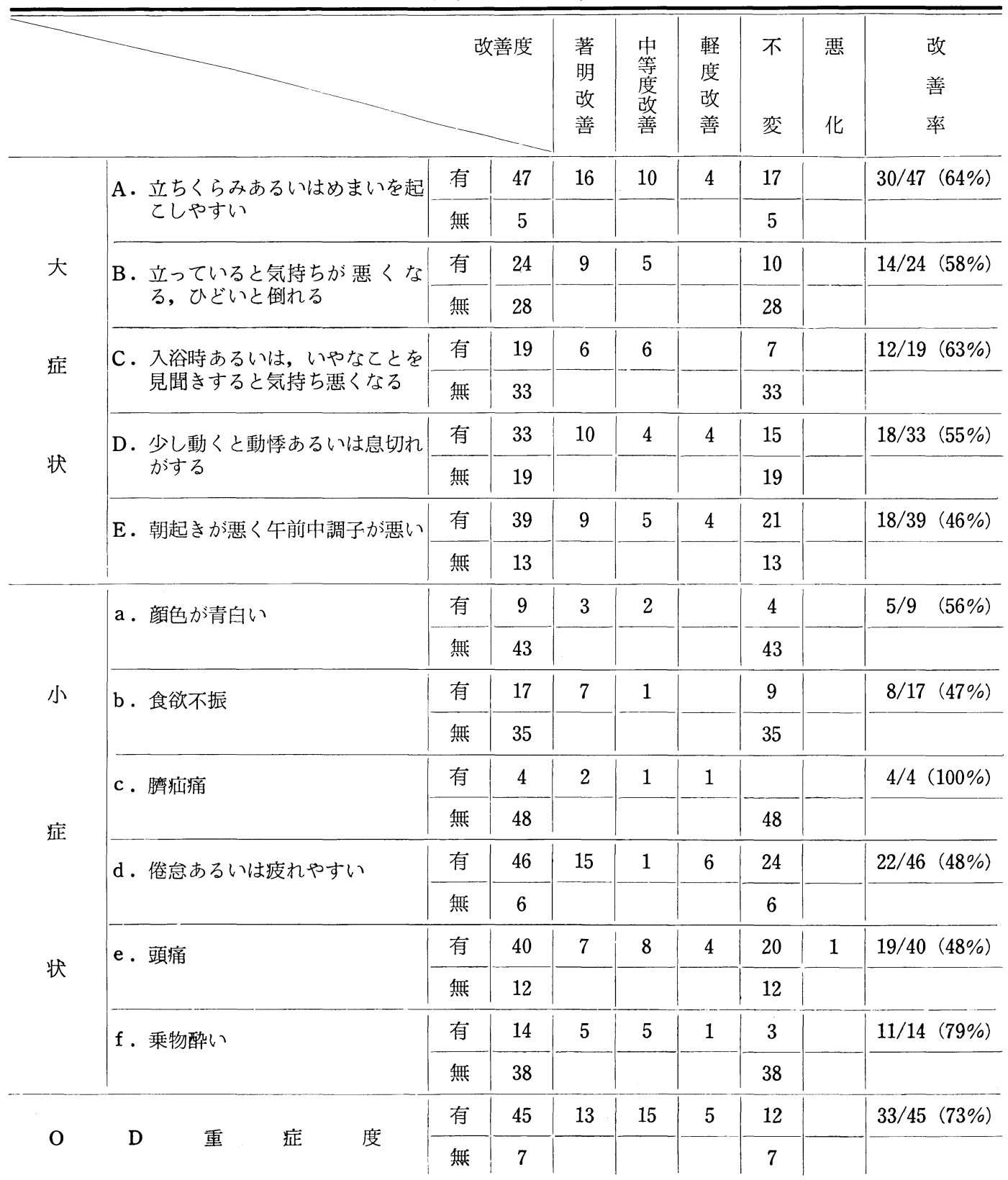


から検討する必要がある. しかし, 実際に治療 となると, 平均発作間隔が長いものでは年余に わたる治療, 経過観察が必要となり, 臨床上効 果の判定に困難な一面がある. 今回, 我々は比 較的短期間に治療効果の判定可能な慢性めまい 症例について検討してみた.

(1) めまいに対する効果

(2) 平衡機能に対する効果
(3) 内耳・中枢神経障害に対する効果

(4) 素因に対する効果

(5) 随伴症状に対する効果

以上より検討した。自覚的症状のみならず， 他覚的所見も把握する必要がある. 症状・所見 の程度分類，評価の基準を設定し， 5 段階に評 価した。この方法により治療効果を的確に，よ り客観的に評価できると考える。

表 9 随伴症状に対する効果

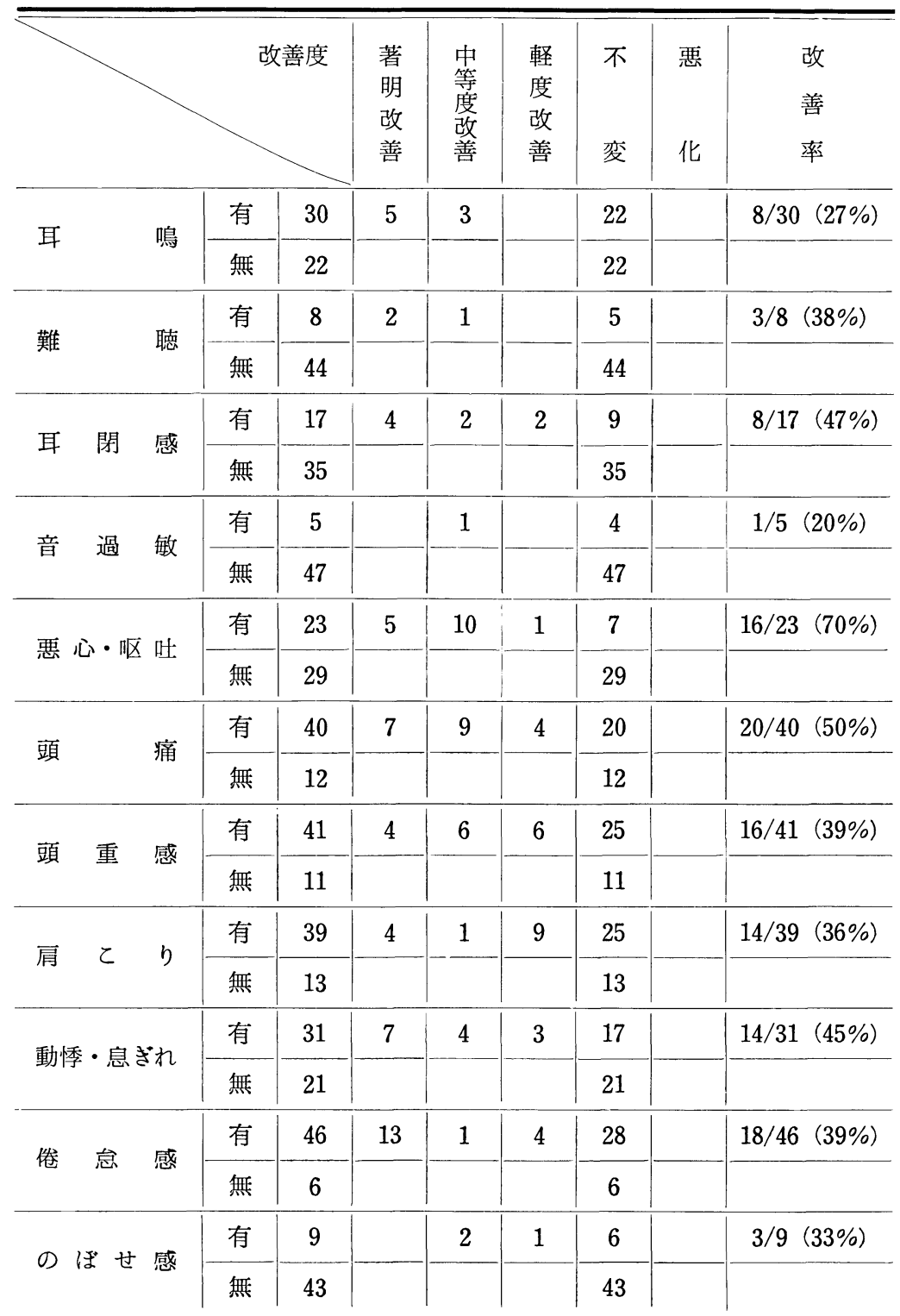


2 ）循環不全を背景とするめまいと Dihydroergotamine について

病歷, 聴力・平衡機能検査, 素因検査により 循環不全を背景とするめまいと診断された症例 は521例中227例 $(43.6 \%)$ を占め, 非常に多か った。このうち，52例に対して，起立性低血圧 に有効とされる Dihydroergotamine を使用し た。その結果，自覚的めまい（69\%), Schellong 起立試験（55\%)，OD症状（73\%）に
対する改善率が高かった。一方，内耳障害（38 $\%)$, 負荷平衡機能検查（27\%）に対する改善 率は低かった。随伴症状に対する効果は種々で あった。 以上, Dihydroergotamine は循環不 全を背景とするめまい例に対して十分期待が持 たれるが, 今後, 反復性めまい症例, 疾患別の 治療効果, 薬剂投与期間のちがいによる効果に ついては検討を要する.

\section{結語}

循環不全を背景とするめまい例に対して，薬物療法を行った，治療効果の評価にあたっては，(1) めまいに対する効果, (2)平衡機能に対する効果, (3)内耳・中枢神経障害に対する効果, (4)素因に対 する効果，(5)随伴症状に対する効果より判定する必要があると考えた.

文

1) Committee on hearing and equilibrium (Chairman : B. R. Alford), Report of subcommittee on equilibrium and its measurment. Meniere's diseae : Criteria for diagnosis and evaluation of therapy for reporting. Jr. f.m. Acad. \& Otol. $76: 1462 \sim 1464,1972$.

\section{献}

2) 時田 喬, 他 : $x$ 二エール病の治療効果の判定. 耳鼻臨床 $73: 1124 \sim 1130,1980$.

別刷請求先 : 斎藤富康 厂500 岐阜市司町 40 岐阜大学医学部耳鼻咽喉科学教室 